\title{
Are We All Nominalists Now?
}

\author{
JUStice Michael KIRBY
}

[Justice Michael Kirby, a judge of the High Court of Australia, sets out to explain the inescapably creative role involved in the work of the court in giving meaning to ambiguous constitutional and statutory words and common law concepts. Uninformed commentators might call judges performing such functions as "nominalists". But few, if any, Australian judges now adhere to constitutional interpretation according to notions of original intent. A "functional" approach is taken. This approach is illustrated by reference to recent cases on the word "alien" and the phrase "trial by jury" in the Australian Constitution. According to the author this is not a weakness but a strength of constitutional elaboration. Judges and lawyers, being concerned about justice under law, are never "on automatic pilot".]

\section{LAW And Justice: Mind And Heart}

It was a very nostalgic walk for me down from the new Commonwealth Law Courts to this place. I walked along William Street past the Supreme Court, where last October the High Court had its Centenary sitting in the Banco Court. A hundred years earlier, exactly to the minute, the first sitting of the High Court of Australia had happened there. ${ }^{1} \quad$ I then turned to the left and walked down Little Bourke Street. I walked past 451 Little Bourke Street, which at the time of my first judicial appointment in December 1974 was the venue of the Australian Conciliation and Arbitration Commission to which I was appointed. It is now a much jazzier building. In those days it was a rather decrepit, Formica type building, if you understand

\footnotetext{
* Justice of the High Court of Australia. Inaugural Speech, The Justice Speeches, La Trobe University Law Students' Association, 30 ${ }^{\text {th }}$ April 2004, held at the Leo Cussen Institute, Melbourne. The ex tempore character of these remarks has been preserved.

1 See 'High Court Centenary' (2003) 77 Australian Law Journal 653, 783.
} 
my drift. I walked then on and past what was, at that stage, the old High Court of Australia building on my left. And down here to the Leo Cussen Institute. It is thirty years since I was first given the title of Justice. I am the second longest serving Justice in our country. The longest serving is Justice Kemeri Murray of the Family Court of Australia. I have threatened to poison her so that I would be number one.

It's an excellent initiative of the Law Students' Association to launch this series. I hope it will stimulate ideas of justice in your minds and in your hearts. We are called to a vocation that is not a purely mechanical one. It is very important to understand that. We are not simply on automatic pilot. Never. We are not simply applying unquestioned rules, which don't involve any input from ourselves. Our input, when it comes, must come from a combination of our mind and our heart. That is how it has been for 800 years of the Common Law. It will be so throughout your lifetime. You will have to make a contribution to it. Law and Justice are a product of mind and heart.

\section{ENTER THE Nominalists}

On Tuesday of this week the High Court was sitting in Canberra. It is a particularly beautiful time of the year in the national capital. All the trees are changing colour. My chambers are on the back, or the front, of the High Court, depending on whether you regard the lake as the front. I look over Parliament House. My chambers have a magnificent sweep of the Brindabellas and of all of the beautiful buildings of Canberra: of the old Parliament House and the new Parliament; of the administrative buildings. I see from the constitutional triangle not only the lovely trees and the nature which is the glory of Canberra but also the seat of government of our country. The High Court of Australia is placed there in the constitutional triangle together with the executive government and the Parliament. We are the symbols of the highest reach of government in Australia.

I was sitting there preparing for the hearing of quite a complicated case. My mind was totally absorbed in the detail of the case. Into the room burst Justice McHugh. His eyes were bright and fiery. He looked at me and he said, 'Do you know that you and I have been called nominalists?' I sat for a moment stunned. That was a mistake. In the law, you must never let anyone know that you are stunned. You must always be ready to seize the moment and to show that you know exactly what is happening around you. I have been called many things in my lifetime. But 'nominalist'. What was a 'nominalist'? He said 'You and I have been called nominalists'. The blood drained from my face as I contemplated what on earth a nominalist could be. I rushed into the High Court reading room, which is adjacent to my chambers. Trembling, I picked up The Australian newspaper. The article in The 
Australian called 'Pink Picket Fence' ${ }^{2}$ contains a report of a submission presented to the federal government concerning the law of marriage. The submission was drafted by the Australian Family Association. In the article its spokesman, Richard Egan, said, in effect, 'We need amendments to the Marriage Act because of the 'nominalists.', This is what was reported:

Egan accused nominalists such as High Court Justices Michael McHugh and Michael Kirby and the Justices of the Supreme Court of Ontario in Canada and Massachusetts in the United States of being Humpty Dumpties who assign marriage no fixed meaning. They say that using their raw judicial power they can, like Humpty Dumpty, simply declare that two men can marry each other or two women may marry each other. Marriage, they say, is not a given reality but a fluid concept that can expand, stretch or redefine as we please. ${ }^{3}$

In the immortal words of Vladimir Ilich Lenin, said Mr Egan, quoting the great revolutionary, 'What is to be done?'

So I sat reading The Australian, in silence. I had to sit down because, as you appreciate, I didn't know what was coming. I then composed myself and thought: are we truly nominalists? Is Justice McHugh sharing with me 'nominalism'? So I thought I should share with you this theory, that is, Mr Egan's theory. Perhaps I should explore it a little in these remarks.

Immediately I knew what Mr Egan was getting at. His reference was to the great case of Re Wakim. ${ }^{4}$ That was the case that undid the cross vesting legislation so far as it purported to permit State Parliaments to confer State jurisdiction on Federal courts. In describing the theory of constitutional interpretation in the High Court, Justice McHugh responded, in Wakim, to some humble remarks I had made in my solitary dissent in that case. I there suggested that the interpretation of the Australian Constitution adopted by the majority was neither necessary nor correct. ${ }^{5}$ In his reasons Justice McHugh explored, in a very important and very interesting and typically well written passage, how courts and especially the High Court of Australia, go about interpreting the sparse language of our constitutional text. This is what he said. Obviously it is what provoked Mr Egan:

... [M] any words and phrases of the Constitution are expressed at such a level of generality that the most sensible conclusion to be drawn from their use in a constitution is that the makers of the Constitution intended that they should have been able to apply to whatever facts and circumstances succeeding generations thought they covered. Examples can be found in the powers conferred on the Parliament of the Commonwealth to make laws with respect to

\footnotetext{
The Australian, 27 April 2004, 9.

3 Ibid.

${ }_{5}^{4}$ Re Wakim; Ex parte McNally (1999) 198 CLR 511.

${ }^{5}$ Ibid $596[178]$ ff.
} 
'trade and commerce' with other countries and among the States or 'external affairs' or 'conciliation and arbitration for the prevention of settlement of industrial disputes.' In these and other cases the test is simply what do these words mean to us as late twentieth century Australians? ... The level of abstraction for some terms of the Constitution is however much harder to identify than that of those set out up above. Thus, in 1901, "marriage" was seen as meaning a voluntary union for life between one man and one woman to the exclusion of all others. If that level of abstraction were now accepted it would deny the Parliament of the Commonwealth the power to legislate for same sex marriages, although arguably "marriage" now means or in the near future may mean, a voluntary union for life between two people to the exclusion of others. ${ }^{6}$

This is clearly the passage which caused Mr Egan to think that Justice McHugh was a 'nominalist'. Of course in the High Court of Australia we have not to this time had to consider what 'marriage' in the marriage power means. ${ }^{7}$ This is because there has not been a case which has presented that matter to the Court. I am not in these remarks going to embark upon what I think it may mean. This is because I have not had the advantage of the arguments of the lawyers and the consideration of the hard facts of a case that will concretise the issue.

However, in a talk I gave at Melbourne University on the subject of methods of constitutional interpretation, I referred to Justice McHugh's remarks in the decision in Wakim. $^{8}$ I said that his remarks indicated, in a very vivid way, how words can take on a different meaning. The words remain the same. But over the passage of time (leave aside 'marriage' for the present purposes) words can take up a different meaning. Courts, giving meaning to the words which the Constitution requires in a contemporary case, have to focus on the word. However, the judges must also keep in mind that a word can acquire a change in content - new nuances of meaning derived from the changing social context in which the word is used. That is the genius of words at least in the English language. It presents the phenomenon of constitutional interpretation.

So I sat there distracted from my labours in the case at hand and thought how many others on the High Court are 'nominalists'? Are there no 'originalists' left who take the view that the words of the Australian Constitution are set in stone? That the meaning of the words is to be found, and found only, by reference to what those words meant in 1900 when the Constitution as adopted by the Imperial Parliament? Or in 1901 when it came into force in Australia? What is the answer to that question?

\footnotetext{
${ }^{6}$ Ibid 551-553, 552-3 (citations omitted).

${ }^{7}$ Australian Constitution, s 51 (xxi).

${ }^{8}$ M D Kirby, 'Constitutional Interpretation and Original Intent: A Form of Ancestor Worship?' (2000)

24 Melbourne University Law Review 1.

${ }^{9}$ See eg Grain Pool of Western Australia v The Commonwealth (2000) 202 CLR 479, 518.
} 


\section{The Constitutional Word 'Aliens'}

Into my mind came flooding case after case in the matters that have been decided in the High Court in the eight years since I was appointed, in which Court has had to look at a word or a little phrase and to give it a meaning. Often, the Court has come to conclusions that, almost certainly, were not the conclusions about the meaning of the word that would have been taken in 1900 or $1901^{10}$

Take for example the decision in Re Patterson; ex parte Taylor. ${ }^{11}$ It is a decision given in 2001. So it is quite a recent decision. That was a case about Mr Taylor who had come to Australia at the age of six. He had migrated from Britain with his parents. He came on the Assistant Migrant Scheme at that time. He was a British subject, as we all were in Australia at that time. He didn't take out Australian citizenship. The overwhelming majority of people who came to Australia from the United Kingdom at that time did not take out Australian citizenship. This was because they did not think it was necessary to go along to a ceremony and swear allegiance to the Queen, given that they already owed that allegiance. Therefore, citizenship was not something that they thought was essential in their case, however much it might be essential or desirable in the case of people who came from other less fortunate lands outside British dominion.

Mr Taylor with his family lived here from his sixth year for several decades. At a certain time, I think he was by this time in his thirties, he committed criminal offences. The Minister for Immigration decided to revoke his 'visa' and to expel him from Australia. Mr Taylor had no family in the United Kingdom. He had no connection with the United Kingdom. He had never been to the United Kingdom since he had arrived to Australia at the age of 6 . Indeed, he had never left this country since the age of 6 . He came to the High Court of Australia and said to the Minister: 'You cannot expel me because I may not be an Australian citizen but I am an Australian national. I am a subject of the Queen. In that capacity I am not an "alien.,"12 My period of "migration" has long since expired. ${ }^{13}$ You cannot deal with me as a migrant or an alien and therefore you cannot expel me.' The basic issue was presented to the High Court in the case of Ex parte Taylor as to what the little word 'alien' in the Australian Constitution meant.

In a case of Nolan $v$ Minister for Immigration and Ethnic Affairs, ${ }^{14}$ more than a decade earlier, the High Court by majority, with Justice Gaudron alone dissenting, held that 'alien' in today's world effectively meant non-citizen. If that determination was correct, then the Minister had the entitlement to expel Mr Taylor from Australia. In Nolan, Justice Gaudron said the word 'citizen' does not appear, relevant to nationality, in the Australian Constitution. ${ }^{15}$ It is a statutory expression. It

\footnotetext{
10 A good illustration is Sue v Hill (1999) 199 CLR 462, 503, 524-526.

11 (2001) 207 CLR 391.

12 Australian Constitution, s 51 (xix).

13 Australian Constitution, s 51 (xxvii)

14 (1988) 165 CLR 178.

15 Ibid 191.
} 
is not a constitutional notion. Therefore, you cannot expel Mr Taylor as a 'noncitizen.' You have got to consider whether you have the power in the Australian Constitution in respect to his nationality.

When Mr Taylor's case came before the High Court, four of the judges in the case, Justices Gaudron, McHugh and Callinan and I held that the arguments of Mr Taylor were correct. We had slightly different reasons for explaining when British nationality had ceased. However, the majority were all convinced that the notion of 'alien', from the beginning of the Australian Constitution and right up to quite recent times, meant in the case that British subjects who were non citizens could still have Australian nationality. They could not be expelled as aliens. ${ }^{16}$

There was then a change in the composition of the High Court of Australia. Justice Gaudron retired. Justice Heydon took her place. The issue came back to the Court because the Minister was not very happy with the decision in Taylor. It came back to the Court in the case of Shaw v Minister for Immigration and Multicultural Affairs ${ }^{17}$ with Justice Heydon replacing Justice Gaudron. That case was decided late last year.

That case effectively amounted to a very rapid challenge, just two years after Taylor, to the decision in Taylor. It was an attempt to restore the 'true' doctrine, as it was put, that had been expressed in Nolan. Justices McHugh, Callinan and I didn't shift our positions. Nor did Chief Justice Gleeson or Justice Gummow and Justice Hayne shift their contrary positions. So it was $3: 3$. It was up to Justice Heydon to deliver the decisive opinion. And when Justice Heydon's opinion came in, it was a very brief one you'll be pleased to hear. ${ }^{18}$ However, it endorsed the view favoured by Chief Justice Gleeson, Justice Gummow and Justice Hayne in Taylor.

The result was that a meaning was given to the constitutional word 'alien.' By majority, 'alien' meant, effectively in this day in age, 'non citizen.' This was so although citizenship is not referred to in the Australian Constitution as one of the powers for the enactment of laws by the Federal Parliament. It is a statutory not a constitutional word.

There are too many references to 'subject of the Queen' in the Australian Constitution ${ }^{19}$ for there to be any doubt that in 1900 the framers of the Constitution would have rejected with a scoff the notion that 'alien' included a subject of the Queen who was born in the United Kingdom within the allegiance of the Queen, and came to this country at the age of six and lived here all his life. In 1900, without any shadow of a doubt, neither Mr Taylor nor Mr Shaw would have been 'aliens.'

It is interesting to look at the qualifications for Members of the Federal Parliament. There is no mention there of their having to be Australian 'citizens.' The reference in the Australian Constitution is only to their having to be a subject of the

\footnotetext{
16 See Re Patterson (2001) 207 CLR 391, 413, 436, 494-495, 518.

17 (2003) 78 ALJR 203; 203 ALR 143. See now Sigh v The Commonwealth (2004) 78 ALJR 1383.

18 (2003) 78 ALJR 203, 235.

19 Australian Constitution, ss 34(ii), 117.
} 
Queen. ${ }^{20}$ Put simply, that was the nationality status in 1900 . So when the Court looked at the word 'alien' today, the issue was how we should interpret it. The majority of the court in Shaw's case held that it didn't mean the opposite of 'subject of the Queen.' At least it did not mean that in terms of the Queen in right of the United Kingdom. It meant effectively, in today's terms, 'non citizen.'

So there stands the debate in that case. An awful thought came across my mind as I sat there in the High Court reading room. Perhaps Chief Justice Gleeson, Justice Gummow, Justice Hayne and Justice Heydon are 'nominalists.' Perhaps they are judges who believe that the word 'alien' has a shifting meaning. They can give a different meaning to the anchor in the text and the meaning of 1900 . They effectively acknowledged a shift in meaning. I shook my head and thought that surely cannot be. Can they be 'nominalists' too? Surely not. But then I reflected on the cases about jury trial.

\section{The Constitutional Phrase: Trial 'By Jury'}

You will remember that there is that small, pathetic, almost unnoticed provision in Section 80 of the Australian Constitution, which says that in trials of indictable offences in federal cases, those trials have to be held 'by jury.' However, the guarantee might just as well not be in the Constitution because the High Court has given meaning to the words 'on indictment' as connoting anything that, by the procedures of the time, is an 'indictable' offence. ${ }^{21}$ Presumably, if the law does not require the matter to be proceeded with on 'indictment,' any case can proceed in a summary way without an indictment. Then it doesn't pick up the right to trial 'by jury.'

This is a view of the interpretation of the Constitution that I don't agree with. However, in respect of Section 80, it is pretty well established in the constitutional doctrine of the High Court. Despite that, over the last four or five years, in my time on the Court, we've had case after case where issues have been presented, about what that little expression 'by jury' means in Section $80 .^{22}$

One case came before my time on the Court in the case of Cheatle $v$ Queen. ${ }^{23}$ It concerned whether or not you could have trial 'by jury' with majority verdicts. In most of the States of Australia, the Jury Acts have been amended to permit, in certain circumstances, majority verdicts. If there is one juror holding out, you can take the verdict from the 11. Or, in some cases, if there are two jurors holding out you can take the verdict from 10. Mr Cheatle was convicted by jury in South Australia on a majority verdict. Because in that case the conviction occurred in a federal trial, of a federal offence in federal jurisdiction, the courts applied, through the Judiciary Act, the procedural laws of the State. ${ }^{24}$ The judge accepted a majority

\footnotetext{
${ }^{20}$ Australian Constitution, s 34(ii).

${ }^{21}$ The King v Bernasconi (1915) 19 CLR 629, 637.

${ }^{22}$ See eg Cheung $v$ The Queen (2001) 209 CLR 1.

23 (1993) 177 CLR 541.

24 Judiciary Act 1903 (Cth) ss 39, 68.
} 
verdict. But Mr Cheatle challenged that course in the High Court. He said, 'by jury' meant 'by a process that is well entrenched in the Constitution.' He threw in for good measure, 'by the meaning of a jury trial in 1901'. So the case came up to the High Court.

The court held that an essential notion of jury trial is unanimity. It's essential because that is what had always been required of jury trials in England. It was required long before Australia was settled and then in every jury trial in colonial times up to the adoption of the Federal Constitution. So what was involved was simply discovering and applying the meaning of the words, 'by jury.'

The High Court had a bit of a problem here. This was because, if the issue of what those words meant had to be determined only by reference to the meaning of jury trial in 1900, it was the law at that time that to be a member of a jury in every colony of Australia, you had to have two qualities. You had to be of the male gender. And the other requirement was that you had to own some property. If you didn't have the property but were of the male gender you couldn't serve. If you were of the male gender and didn't have the property you couldn't serve. If you were a female you just couldn't serve as a juror at all. You could be a very wealthy female, but you were not entrusted with serving on juries.

And so it was in Cheatle that the Court held that unanimity was essential for jury trial. They held that on the basis that, that was what was required in the Common Law and in the Court's practice up to the Australian Constitution. But the Court went on to say that there were some features of jury trial at the time when the Australian Constitution was adopted that had not been carried into the constitutional meaning today, such as the male gender or property qualifications. ${ }^{25}$ Since Cheatle was decided, one after another we have had cases in which the question has arisen as to whether innovations in jury trial that have been introduced in the State jurisdictions could be practised in federal jurisdiction.

For example, can you separate the jury? If you go to the library at the Supreme Court in Melbourne, above the wonderful rotunda are the rooms where jurors who were trying a case were kept overnight. There were bunks there. The conditions were, shall we say, pretty primitive. But jurors were not separated. They could not leave the precincts of the court and the control of the Sheriff's officer whilst they were conducting a trial. This was because the accused had been placed 'upon his country.' The solemn responsibility of the jury (in many cases concerning the life and death of the prisoner) was to stay together. In this way they would be completely immured from external influences, pressure, bribery, corruption or anything else. It was the rule of the time and absolutely strictly adhered to.

The question arose in Brownlee's case ${ }^{26}$ whether in today's age, where jurors want to get home to their children and to their families, cook the dinner and get on with life, we would tolerate in federal trials what had been permitted in State jurisdictions? Or whether that was forbidden by the constitutional words 'by jury' in Sec-

\footnotetext{
25 (1993) 177 CLR 541, 560. They were called "undesirable features.",

${ }^{26}$ Brownlee v The Queen (2001) 207 CLR 278.
} 
tion 80? The High Court held that the verdict still had to be unanimous. But that the jurors may separate. They don't have to be kept together and remain locked up even whilst deliberating. The Court also held that there can be reserve jurors. Trials now go on for much longer than typically they did in the $19^{\text {th }}$ Century. Many of the States have provisions for reserve jurors. The question arose as to whether that could come within the little phrase 'by jury' ${ }^{27}$ The High Court held that juror separation and reserve jurors were within trial 'by jury.' But no to male qualifications and no to property rights.

So what is the distinction which has informed the decision that 'by jury' picks up certain matters which were a phenomenon of $19^{\text {th }}$ Century jury trial before the Australian Constitution was adopted, but not other matters which are a feature of jury trial in most parts of Australia today? Once again, an awful thought crossed my mind that the judges who had agreed to the separation of the juries and had agreed to allow women on juries and who had agreed that you didn't have to have property rights to become a juror and agreed that juries could include reserve jurors where other jurors fell ill; perhaps they were 'nominalists' too? This would mean all members of the Court. It is a tantalising question, isn't it, to consider whether we are all 'nominalists' now? And if so, in the immortal words of V.I Lenin, 'What is to be done?'

\section{Living On A Legal Knife’s Edge}

The way in which we resolve these questions requires judicial technique and also a theory about the Australian Constitution. Not every case involves the Australian Constitution. We heard a case yesterday in the High Court which had three very intriguing points in it. One of them concerned whether it is a 'reasonable excuse' within the meaning of the criminal justice amendments in Western Australia, for police to agree to a suggested request by the accused to switch off the video recording whilst the accused is making a statement to police. During the period off camera the accused allegedly made what are said to be confessional statements that are damaging. Is it 'reasonable excuse' that the accused is alleged to have said, 'switch off the camera'? Or, if that were accepted as a 'reasonable excuse,' would it drive a horse and cart through the purpose of the criminal law and procedures of Western Australia that oblige the video taping of confessions to police in those circumstances?

There were two other very interesting points in the case. One of them concerned collateral evidence. That is to say, when do you exceptionally permit collateral evidence to be received into evidence in a trial even though it is hearsay, and doesn't prove the truth of the matter that is involved? The case involved a prisoner in custody who alleged that a person who gave evidence against the accused had confessed in prison to another prisoner, effectively, that he was going to 'fit' the

\footnotetext{
${ }^{27}$ Fittock v The Queen (2003) 77 ALJR 961; Ng v The Queen (2003) 77 ALJR 967.
} 
accused who was the appellant in our Court. The legal problem is a well known problem. How do you draw the line, a line of principle, between permitting a person to give probative evidence, whilst not chasing every hare down its burrow? Courts don't, as it were, look at every issue on the footing that what is said, even if proved, would merely prove that the person said something that would not necessarily prove that it was true.

As I was listening to this case, I leant over to Justice Callinan and I said 'We have a very stressful life here, do you realise this? Every case has problems which are right at the cusp.' 'We are living,' I said, trembling, to Justice Callinan '...we are living on a knife's edge. We have to decide about juries, about aliens, about collateral evidence, about 'reasonable excuse'. Every day is presenting us with really difficult questions. They may be questions of the Constitution. They may be questions of statutory construction. They may be questions to the common law. But they are always on a knife's edge. That is where we live.' He smiled knowingly and we went back to the case.

I've come along to this Justice Lecture today to tell you how difficult the life of a Justice of the High Court of Australia is. I have done so in order that you will all appreciate how hard we have to work: how we give you our reasons at considerable length so that you will understand the working of our minds and see the considerations which have led us to one result or another. It is in the very nature of the decisions of the kind I have told you about, the considerations relating to the 'marriage' power if you like, or to the 'aliens' power, or to trial 'by jury' or to collateral evidence or to the interpretation of a statute that talks of 'reasonable excuse'. All such decisions are disputable. For none of them is there an easy, simple solution.

It is of the nature of the questions that we must resolve in the High Court of Australia that we don't have an easy ride. There are no simple answers. Certainly, by the time you get to the High Court of Australia, if it is a simple case, it ought not be there. And normally it doesn't get there. That's why simplistic notions about 'nominalists' or 'originalists' have to be rejected by lawyers. Such labels oversimplify the very function which the Australian Constitution gives to our judges. Moreover, they oversimplify the function that all of the judges perform and always have performed and always will perform, in defending the rule of law and seeking to uphold equal justice under law.

What is new about our age is that there is much more candour on the part of judges concerning their performance and about the considerations that are taken into account. About whether you take into account an idea of the function of a jury trial as required in the Australian Constitution. About what the Australian Constitution is getting at by requiring that function. Does that notion of the function forbid the taking of a view that will allow the section of the Australian Constitution to be made worthless by a simple change of procedure (indictable or non indictable)? What is our Constitution there for? What is its purpose? Giving meaning to the words in the Australian Constitution according to the purpose of a living Constitution for a free people is the most important task that the High Court of Australia performs. 